\title{
PENGARUH KONSENTRASI KADMIUM TERHADAP PERUBAHANWARNA DAN PERSENTASE JENIS KELAMIN JANTAN ANAKAN Daphnia magna
}

\section{INFLUENCES CONCENTRATION OF CADMIUM TO COLOUR CHANGE AND MALE SEX PERCENTAGE NEONATES Daphnia magna}

\author{
Alfi Hermawati W. S., Rahayu Kusdarwati, Setyawati Sigit dan A. Shofy Mubarak \\ Fakultas Perikanan dan Kelautan Universitas Airlangga \\ Kampus C Mulyorejo - Surabaya 60115 Telp. 031-5911451
}

\begin{abstract}
Cadmium is one of dangerous heavy metal and it can cause water pollution. As an alternative early warning toward heavy metal in water, Daphnia magna can be used as biology indicator water pollution that caused by heavy metal.

Daphnia magna is organism that ussualy used for bioassay in many progressing countries, because that organism have important role in freshwater ecology, short life cycle about 3 weeks and sensitive toward chemical environment. Grade of toxicity heavy metal can measured with lethal and sub lethal parameter. In Daphnia magna, sub lethal parameter that can be observe are colour changes and male sex percentage neonates.

The purpose of this research was to know the colour changes and male sex percentage neonates Daphnia magna in different concentration of cadmium. Target of this research is to gets information about level colour changes and male sex percentage neonates Daphnia magna in different concentration of cadmium. The main parameter was colour changes and male sex percentage neonates and the secondary parameters were water quality (temperature, $\mathrm{pH}$, dissolved oxygen and $\mathrm{NH}_{3}$ )

The result of research of giving different cadmium concentration to the adult female Daphnia magna not showing significant influence, nevertheless it is showing significant influence toward male sex percentage neonates Daphnia magna. The treatment with cadmium concentration 0,0004 mg/l produce 100\% male neonates Daphnia magna. Water quality during research were in optimal conditions to support Daphnia magna life, those are temperature $26^{\circ} \mathrm{C}, \mathrm{pH}$ range from $8,0-8,2$ and dissolve oxygen (DO) range from $8,5-9,0 \mathrm{mg} / \mathrm{l}$ and ammonia $0-0,03 \mathrm{mg} / \mathrm{l}$.
\end{abstract}

Key words : cadmium, Daphnia magna, colour changes and male sex percentage neonates.

\section{Pendahuluan}

Semakin meningkatnya kegiatan manusia, terutama dalam bidang industri mendorong masalah pencemaran air oleh buangan limbah industri juga semakin meningkat. Salah satu masalah yang disebabkan oleh buangan limbah industri tersebut adalah bahaya toksisitas logam berat. Salah satunya adalah logam berat kadmium (Sunarto, 2007).

Sebagai salah satu alternatif dalam upaya deteksi dini adanya logam berat perairan adalah dengan menggunakan indikator biologis Daphnia magna. Organisme tersebut banyak dikembangkan sebagai uji toksisitas di berbagai negara maju, karena Daphnia magna memiliki peran penting dalam ekologi air tawar, siklus hidupnya yang cepat yakni selama tiga minggu serta sensitif terhadap kimia lingkungan (Olmsteated, 2003).

Tingkatan toksik logam berat dapat ditentukan dengan menggunakan parameter lethal dan sub lethal (Waldichuk, 1979 dalam
Connel and Miller, 1995). Pada Daphnia magna, parameter sub lethal yang diamati meliputi tingkatan perubahan warna dan persentase jenis kelamin jantan anakan yang dihasilkan (Rider et al., 2005). Berdasarkan hal tersebut, perlu dilakukan penelitian tentang pengaruh konsentrasi kadmium terhadap perubahan warna dan persentase jenis kelamin jantan anakan Daphnia magna.

Tujuan penelitian adalah untuk mengetahui tingkatan perubahan warna Daphnia magna pada beberapa konsentrasi kadmium (Cd) dan persentase jenis kelamin jantan anakan Daphnia magna pada beberapa konsentrasi kadmium (Cd).

Kegunaan penelitian ini diharapkan dapat memberikan informasi mengenai tingkatan perubahan warna dan persentase jenis kelamin jantan anakan yang dihasilkan Daphnia magna akibat pemaparan bahan toksik logam berat kadmium agar dapat menjadi dasar pengembangan alternatif deteksi dini perubahan 
lingkungan menggunakan bioindikator Daphnia magna dalam membangun kewaspadaan terhadap akibat pencemaran lingkungan perairan.

\section{Materi dan Metodologi Penelitian}

Penelitian ini dilaksanakan pada tanggal 8 - 20 September 2008 di Laboratorium Pendidikan Perikanan, Program Studi Budidaya Perikanan, Fakultas Perikanan dan Kelautan, Universitas Airlangga.

Materi penelitian yang digunakan terdiri dari bahan dan alat penelitian. Bahan yang digunakan adalah Daphnia magna betina dewasa (D4), senyawa logam berat kadmium klorida $\left(\mathrm{CdCl}_{2}\right)$ sebanyak $0,1 \mathrm{~g}$ dengan konsentrasi kadmium sebesar 0,0613 \% (g / 100 $\mathrm{ml}$ ), air tawar yang telah dijaga kualitas airnya dalam kondisi optimal. Alat penelitian yang digunakan adalah mikroskop, obyek glass, cover glass, pipet, saringan, aerator enam titik, selang aerasi, termometer, amoniak tes kit, $\mathrm{pH}$ meter, tisu, dan wadah perlakuan.

Metode penelitian yang digunakan adalah Rancangan Acak Lengkap (RAL). Pemberian konsentrasi logam berat kadmium dalam penelitian ini adalah perlakuan A (tanpa pemberian kadmium) sebagai kontrol, perlakuan B 0,0001 mg/l, perlakuan C 0,0002 mg/l, perlakuan D $0,0003 \mathrm{mg} / \mathrm{l}$ dan perlakuan $\mathrm{E}$ $0,0004 \mathrm{mg} / \mathrm{l}$. Setiap perlakuan diberikan ulangan sebanyak empat kali.

\section{Persiapan Penelitian}

Peralatan yang akan digunakan dicuci sampai bersih kemudian dibilas dengan air tawar. Peralatan yang sudah bersih kemudian dikeringkan selama 24 jam.

Penentuan Dosis Logam Berat Kadmium Uji toksisitas perlakuan konsentrasi kadmium $\left(\mathrm{CdCl}_{2}\right)$ berada pada kisaran nol sampai dengan LC 50 selama 48 jam (Soemirat, 1994). Penentuan LC 50 dilakukan terlebih dahulu untuk mendapatkan ambang batas konsentrasi toksitan. Bahan yang digunakan, antara lain: 50 ekor Daphnia magna betina dewasa (D4) dalam 1 liter air. Pemaparan logam berat kadmium berlangsung selama 48 jam. Setelah itu, dilakukan pengamatan jumlah Daphnia magna yang hidup dan mati. Data diolah dengan regresi linier $(\mathrm{Y}=\mathrm{a}+\mathrm{bx})$ untuk mendapatkan nilai LC 50 selama 48 jam. Berdasarkan rumus persamaan $\mathrm{y}=-39503 \mathrm{x}+$ 40,883 didapatkan LC 50 Daphnia magna sebesar $0.0004 \mathrm{mg} / \mathrm{l}$.

\section{Persiapan Media}

Media yang digunakan adalah air tawar (PDAM) yang diaerasi terlebih dahulu selama tiga hari untuk menjaga kualitas air dalam kondisi optimal. Selanjutnya dilakukan pengukuran kualitas air yang optimum untuk pertumbuhan Daphnia magna.

\section{Penyediaan Induk Betina Daphnia magna}

Induk Daphnia magna diperoleh dari hasil penetasan ephippium. Setelah empat hari Daphnia magna menjadi dewasa (D4), Daphnia magna tersebut siap untuk digunakan untuk perlakuan uji toksisitas.

\section{Pengamatan Perubahan Warna}

Sebanyak 20 ekor Daphnia magna matang gonad dipelihara dalam wadah dengan volume air sebanyak setengah liter dengan beberapa konsentrasi logam berat kadmium, perubahan warna diamati setelah uji toksisitas 48 jam dengan metode skoring warna menurut Dekken (2005). Setiap perlakuan diambil sebanyak lima ekor sampel, kemudian diskoring menurut perubahan warna yang terjadi.

\section{Pengamatan Jenis Kelamin Jantan Anakan}

Pengamatan jenis kelamin jantan anakan dilakukan pada hari kelima dengan mengambil anakan Daphnia magna pada tiap perlakuan sebanyak 5 ekor, selanjutnya dilakukan identifikasi dan penghitungan jumlah anakan jantan dan betina menggunakan mikroskop dengan pembesaran seratus kali.

Parameter utama yang digunakan dalam penelitian ini adalah perubahan warna dan jumlah jenis kelamin jantan anakan Daphnia magna, sedangkan parameter

\section{Daphnia Color Scale}

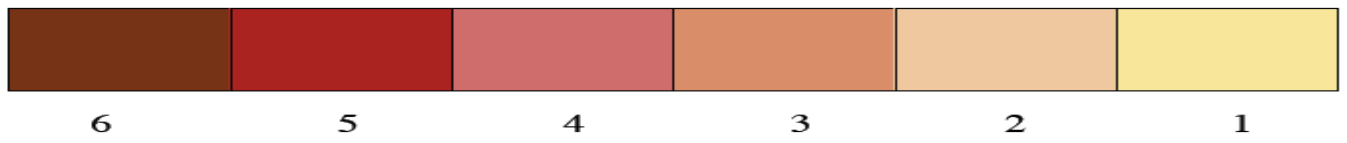

(Sumber: Dekken, 2005) 
pendukungnya adalah oksigen terlarut (DO), suhu air, $\mathrm{pH}$, dan amoniak.

Parameter Utama

Perubahan Warna

Perubahan warna diamati setelah waktu 48 jam dengan metode skoring warna menurut Dekken (2005). Setiap perlakuan diambil sebanyak lima ekor sampel Daphnia magna, kemudian diskoring menurut perubahan warna yang terjadi.

Persentase Jenis Kelamin Jantan Anakan

Penghitungan jumlah jenis kelamin jantan anakan Daphnia magna dilakukan pada hari kelima dengan mengambil anakan Daphnia magna pada tiap perlakuan sebanyak lima ekor, selanjutnya dilakukan identifikasi dan penghitungan jumlah anakan jantan. Zairin (2002) menyatakan, persentase jenis kelamin dapat dihitung dengan rumus :

Persentase jantan $=$

Jumlah individu jantan x $100(\%)$

Jumlah total

Parameter Pendukung

Pengukuran Oksigen Terlarut (DO)

Alat DO meter dikalibrasi terlebih dahulu hingga menunjukkan angka nol, kemudian ujung hitam DO meter dimasukkan kedalam media air percobaan, lalu dibiarkan kurang lebih tiga menit. Kemudian baru dilakukan pencatatan hasil pengukuran DO.

Pengukuran Suhu Air

Termometer air dimasukkan ke dalam air lalu dibiarkan kurang lebih satu menit, kemudian dilakukan pencatatan hasil yang tertera pada termometer tersebut.

Pengukuran Derajat Keasaman $(\mathrm{pH})$

Derajat keasaman (pH) pen dimasukkan ke dalam air sampai probe menyentuh air sekitar $1 \mathrm{~cm}$. Kemudian tombol on dinyalakan dan dibiarkan sebentar sampai nilai $\mathrm{pH}$ yang tertera tidak berubah, hasilnya kemudian dicatat.

Pengukuran Kadar Amoniak

Prosedur pengukuran kadar amoniak menggunakan amoniak test kit antara lain, mengambil sampel air yang akan diukur sebanyak $5 \mathrm{ml} \mathrm{ke} \mathrm{dalam} \mathrm{gelas} \mathrm{pengukur,} \mathrm{lalu}$ ditambahkan 14 tetes reagen 1, kemudian dilakukan pengocokan. Selanjutnya ditambahkan reagen 2 dan 3 dengan cara yang sama dengan reagen 1 sebanyak tujuh tetes. Setelah itu, dibiarkan selama 20 menit, air sampel akan berubah warna. Kemudian warna air sampel dicocokkan dengan indikator warna pada prosedur penggunaan untuk diketahui kadar amoniak pada air sampel.

Analisis Data

Data penelitian persentase jenis kelamin jantan anakan Daphnia magna dianalisis secara statistik dengan mengunakan ANOVA Rancangan Acak Lengkap (RAL). Data yang dihasilkan bila terdapat perbedaan dapat dilakukan uji lanjutan. Uji lanjutan yang dapat digunakan adalah Uji Jarak Berganda Duncan (Duncan Multiple Range Test) (Kusriningrum, 2008). Sedangkan data penelitian perubahan warna Daphnia magna dianalisis secara statistik dengan uji Kruskal Wallis H Test (Samsubar, 1996).

\section{Hasil dan Pembahasan}

Pengamatan perubahan warna Daphnia magna dilakukan setelah perlakuan pemaparan dengan konsentrasi kadmium $\left(\mathrm{CdCl}_{2}\right)$ yang berbeda diukur menggunakan standar Daphnia color scale (Dekken, 2005) yang memiliki 6 nilai skor (skor 1 - 6), skor 1 merupakan nilai skor terendah. Hasil pengamatan skoring perubahan warna pada Daphnia magna tersebut ditunjukkan pada Tabel 1.

Tabel 1. Skoring tingkatan perubahan warna Daphnia magna setelah uji toksisitas selama 48 jam dengan perlakuan konsentrasi kadmium $\left(\mathrm{CdCl}_{2}\right)$.

\begin{tabular}{|c|c|}
\hline Perlakuan $(\mathrm{mg} / \mathrm{l})$ & Skoring Warna \\
\hline A (kontrol) & 1,10 \\
B $(0,0001)$ & 1,10 \\
C $(0,0002)$ & 1,15 \\
D $(0,0003)$ & 1,20 \\
E $(0,0004)$ & 1,20 \\
\hline
\end{tabular}

Berdasarkan Tabel 1, pemaparan konsentrasi kadmium $\left(\mathrm{CdCl}_{2}\right)$ pada perlakuan D $(0,0003 \mathrm{mg} / \mathrm{l})$ dan E $(0,0004 \mathrm{mg} / \mathrm{l})$ memiliki nilai rata - rata skoring warna yang sama dan lebih tinggi dibandingkan dengan perlakuan lainnya, yaitu 1,20 , sedangkan perlakuan $\mathrm{C}$ $(0,0002 \mathrm{mg} / \mathrm{l})$ memiliki nilai rata - rata skoring 1,15 . Nilai ini lebih tinggi dibandingkan dengan rata - rata skoring perlakuan A (kontrol) dan B $(0,0001 \mathrm{mg} / \mathrm{l})$ yang masing - masing memiliki nilai yang sama, yaitu 1,10 . Berdasarkan hasil uji statistik terhadap tingkatan perubahan warna 


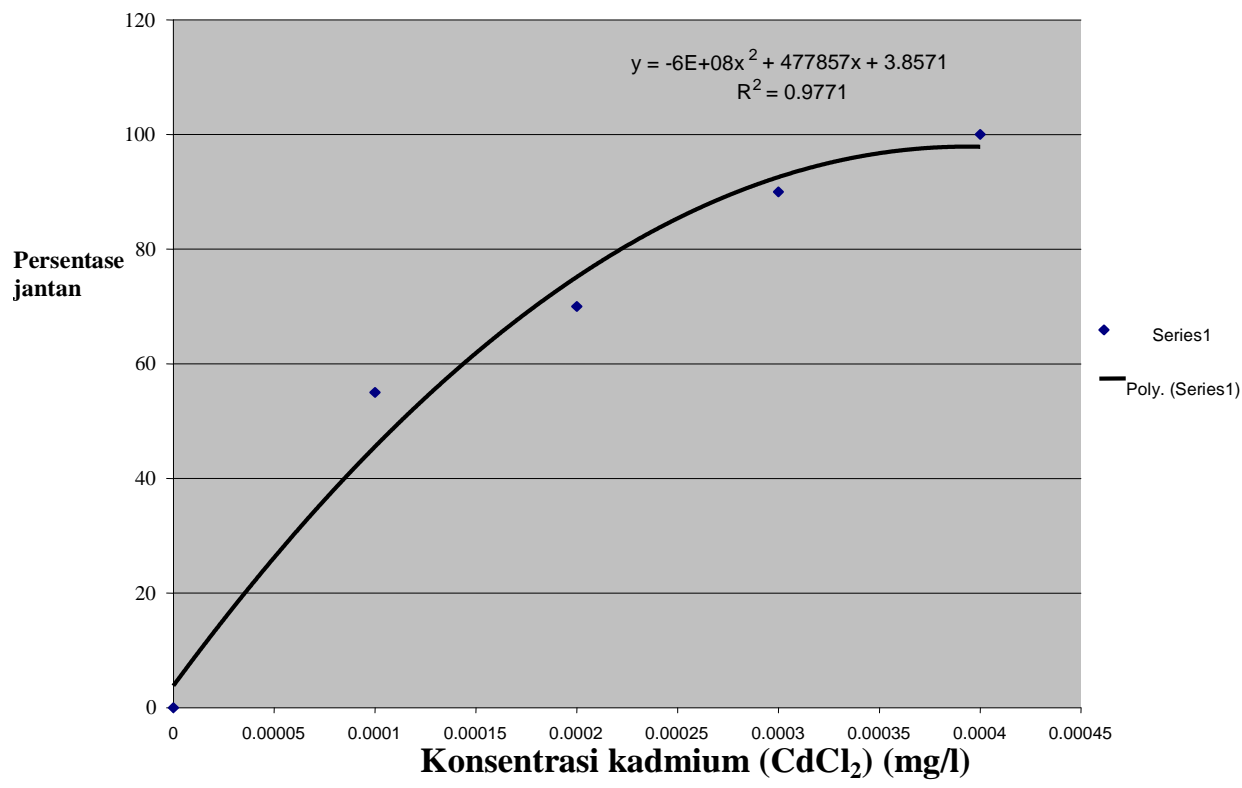

Gambar 1. Grafik hubungan perlakuan konsentrasi kadmium $\left(\mathrm{CdCl}_{2}\right)$ yang berbeda pada Daphnia magna terhadap persentase anakan jantan.

Daphnia magna menunjukkan bahwa $\mathrm{H}$ hitung terkoreksi $<\mathrm{H}$ tabel 0,05 , yang berarti bahwa pada perlakuan pemberian konsentrasi kadmium $\left(\mathrm{CdCl}_{2}\right)$ yang berbeda tidak terdapat perbedaan yang nyata terhadap perubahan warna Daphnia magna.

Hasil pengamatan tentang pengaruh konsentrasi $\operatorname{kadmium}\left(\mathrm{CdCl}_{2}\right)$ terhadap persentase jenis kelamin jantan anakan Daphnia magna dapat dilihat pada Tabel 2.

Tabel 2. Jumlah jenis kelamin jantan anakan Daphnia magna pada perlakuan konsentrasi kadmium $\left(\mathrm{CdCl}_{2}\right)$ dengan konsentrasi berbeda.

\begin{tabular}{|c|c|}
\hline $\begin{array}{c}\text { Perlakuan Konsentrasi } \\
\text { Kadmium } \mathrm{CdCl}_{2}(\mathrm{mg} / \mathrm{l})\end{array}$ & $\begin{array}{c}\text { Jumlah jenis } \\
\text { kelamin jantan } \\
(\%)\end{array}$ \\
\hline $\mathrm{A}($ kontrol$)$ & $0^{\mathrm{d}}$ \\
$\mathrm{B}(0,0001)$ & $55^{\mathrm{c}}$ \\
C (0,0002) & $70^{\mathrm{c}}$ \\
D (0,0003) & $90^{\mathrm{b}}$ \\
E (0,0004) & $100^{\mathrm{a}}$ \\
\hline
\end{tabular}

Keterangan : superskrip yang berbeda pada kolom yang sama menunjukkan hasil persentase jenis kelamin jantan anakan Daphnia magna yang berbeda sangat nyata $(\mathrm{p}<0.01)$

Hasil ANOVA menunjukkan perlakuan konsentrasi kadmium $\left(\mathrm{CdCl}_{2}\right)$ memberikan pengaruh yang berbeda sangat nyata $(\mathrm{p}<0,01)$ terhadap persentase anakan jantan Daphnia magna. Hasil Uji Jarak Berganda Duncan menunjukkan bahwa persentase anakan jantan Daphnia magna tertinggi terdapat pada perlakuan E $(0,0004 \mathrm{mg} / \mathrm{l})$ berbeda nyata dengan perlakuan lainnya. sedangkan perlakuan C $(0,0002 \mathrm{mg} / \mathrm{l})$ dan B $(0,0001 \mathrm{mg} / \mathrm{l})$ menunjukkan hasil yang sama dan perlakuan A (kontrol) merupakan perlakuan dengan persentase anakan jantan terendah. Grafik hubungan perlakuan konsentrasi kadmium $\left(\mathrm{CdCl}_{2}\right)$ yang berbeda pada Daphnia magna terhadap persentase anakan jantan dapat dilihat pada Gambar 1.

Peningkatan konsentrasi kadmium $\left(\mathrm{CdCl}_{2}\right)$ yang dipaparkan pada induk Daphnia magna menunjukkan kolerasi positif terhadap jumlah anakan jantan yang dihasilkan, semakin tinggi konsentrasi kadmium $\left(\mathrm{CdCl}_{2}\right)$ yang dipaparkan pada induk Daphnia magna, semakin banyak pula jumlah anakan jantan yang dihasilkan. Pemaparan konsentrasi kadmium $\left(\mathrm{CdCl}_{2}\right)$ pada konsentrasi $0,0004 \mathrm{mg} / \mathrm{l}$ (LC 50) menghasilkan $100 \%$ anakan jantan (Gambar 1).

Adapun hasil pengukuran kualitas air pada awal perlakuan uji toksisitas antara lain, suhu air $26^{\circ} \mathrm{C}$, derajat keasaman $(\mathrm{pH})$ berkisar $8,0-8,2$, oksigen terlarut (DO) berkisar antara $8,5-9,0 \mathrm{mg} / \mathrm{l}$ dan amoniak 0,03 mg/l, sedangkan hasil pengukuran kualitas air pada akhir perlakuan uji toksisitas meliputi, suhu air $26^{\circ} \mathrm{C}$, derajat keasaman $(\mathrm{pH})$ berkisar $8,2-8,3$, 
oksigen terlarut (DO) $8,5 \quad-\quad 9,0 \mathrm{mg} / \mathrm{l}$ dan amoniak $0,03 \mathrm{mg} / \mathrm{l}$.

Daphnia magna berkembang biak secara seksual dan aseksual. Perkembangbiakan secara aseksual dilakukan dengan parthenogenesis yaitu kemampuan berkembang biak tanpa adanya fertilisasi yang menghasilkan anakan berkelamin betina (Clare, 2002).

Populasi yang terlalu padat serta kualitas dan kuantitas pakan yang menurun akan menginduksi produksi anakan berkelamin jantan (Hebert, 1978 dalam Rider et al, 2005). Kualitas air yang tidak mendukung juga mempengaruhi siklus reproduksi Daphnia magna. Terbentuknya anakan jantan menyebabkan perubahan siklus reproduksi Daphnia magna dari aseksual menjadi reproduksi seksual (Ebert, 2005).

Penelitian ini, menggunakan Daphnia magna betina dewasa (D4). Mokoginta (2003) menyatakan bahwa Daphnia magna sudah menjadi dewasa dalam waktu empat hari (D4), sedangkan kepadatan populasi Daphnia magna yang digunakan dalam penelitian ini, yaitu sebanyak 20 ekor / 0,5 1. Kepadatan tersebut masih berada dalam kisaran yang optimum untuk perlakuan uji toksisitas. USEPA (1996) menyatakan bahwa untuk uji toksisitas, Daphnia magna yang digunakan diharapkan tidak melebihi 40 ekor/l. Selain itu, pemberian pakan yang cukup (diural feeding) serta parameter kualitas air yang meliputi oksigen terlarut (DO), suhu, amoniak dan derajat keasaman $(\mathrm{pH})$ juga dikondisikan optimum selama perlakuan pemaparan konsentrasi kadmium $\left(\mathrm{CdCl}_{2}\right)$. Berdasarkan hal tersebut, pakan dan kepadatan populasi serta kualitas air bukan lagi menjadi streesor pembentukan anakan jantan. Hal ini terlihat dari perlakuan A (kontrol) yang menghasilkan $0 \%$ anakan jantan (100\% anakan betina).

Berdasarkan hasil ANOVA menunjukkan bahwa perlakuan A (kontrol) merupakan perlakuan yang menghasilkan persentase anakan jantan terendah dibandingkan dengan perlakuan lainnya, sedangkan perlakuan B $(0,0001 \mathrm{mg} / \mathrm{l})$ menunjukkan hasil yang sama dengan perlakuan $\mathrm{C}(0,0002 \mathrm{mg} / \mathrm{l})$ hal ini berarti bahwa pada kedua perlakuan konsentrasi kadmium $\left(\mathrm{CdCl}_{2}\right)$ tersebut memberikan pengaruh yang sama terhadap persentase anakan jantan Daphnia magna, namun peningkatan pemberian konsentrasi kadmium $\left(\mathrm{CdCl}_{2}\right)$ menunjukkan pengaruh yang berbeda nyata. Hal ini terlihat dari perlakuan D $(0,0003 \mathrm{mg} / \mathrm{l})$ dan $\mathrm{E}$ $(0,0004 \mathrm{mg} / \mathrm{l})$ yang menunjukkan hasil yang berbeda nyata yang mana perlakuan E $(0,0004)$ menghasilkan persentase anakan jantan tertinggi yaitu sebesar $100 \%$ yang berbeda nyata dengan perlakuan lainnya. Hal ini menunjukkan, bahwa semakin tinggi pemaparan konsentrasi $\left(\mathrm{CdCl}_{2}\right)$ semakin banyak pula anakan jantan Daphnia magna yang dihasilkan.

Toksitan kadmium $\left(\mathrm{CdCl}_{2}\right)$ mempengaruhi deferensiasi jenis kelamin anakan Daphnia magna. LeBlanc et al. (2005) menyatakan, stressor kimia lingkungan dapat memberikan respon balik terhadap sintesis ecdysteroid yang berperan sebagai testosterone antagonizes. Stresor tersebut memberikan respon pada protein reseptor, kemudian terjadi regulasi negatif yang ditandai dengan aktifnya sintesa terpenoid hormon yakni Methyl Farnesoate. Hal ini menyebabkan kegagalan pembentukan kelamin betina oleh ecdysteroidreceptor transcription factor (E:EcR:RXR), sehingga terbentuklah kelamin jantan (LeBlanc et al., 2005)

Ochlan and Ochlman (2003) menambahkan bahwa kadmium merupakan toksitan yang dapat menurunkan level ecdysteroid crustacea, penurunan ini berpengaruh terhadap perubahan jenis kelamin Daphnia magna dengan terbentuknya anakan jantan Daphnia magna oleh karena terjadinya penghambatan terhadap ecdysteroid dan teraktifasinya pembentukan Methyl Farnesoate. Seperti halnya Olmsteated and LeBlanc (2002) yang menyatakan bahwa Methyl Farnesoate berperan dalam menentukan jenis kelamin anakan Daphnia magna pada induk matang telur dalam ovari. Semakin tinggi konsentrasi kadmium $\left(\mathrm{CdCl}_{2}\right)$ semakin banyak Daphnia magna yang terinduksi untuk memproduksi Methyl Farnesoate, sehingga semakin besar persentase anakan jantan yang dihasilkan.

Rider et al. (2005) menyatakan, sintesa haemogloblin diatur oleh hormon terpenoid (Methyl Farnesoate), konsentrasi haemoglobin meningkat secara singnifikan pada pemaparan hormon Methyl Farnesoate. Potensi hormon terpenoid untuk meningkatkan konsentrasi haemoglobin dan induksi anakan jantan berkorelasi positif. Terbentuknya anakan jantan Daphnia magna pada penelitian ini mengindikasikan terjadinya peningkatan Methyl Farnesoate. Namun demikian, tidak terjadi peningkatan sintesa haemoglobin. Hal ini berdasarkan hasil nilai skoring warna yang tidak signifikan pada pemaparan kadmium $\left(\mathrm{CdCl}_{2}\right)$ hingga konsentrasi LC 50 anakan jantannya mencapai $100 \%$.

Dekken (2005) menyatakan bahwa pada kondisi oksigen rendah (hypoxia) Daphnia magna yang akan meningkatkan produksi haemoglobin, sehingga pada bagian luar 
carapace akan terlihat berwarna merah. Peningkatan produksi haemoglobin tersebut bertujuan untuk membantu transportasi oksigen di dalam tubuh, sehingga pada saat oksigen lingkungan rendah, Daphnia magna meningkatkan kebutuhan oksigennya.

Haemoglobin Daphnia magna terdiri atas sub unit hb1, hb2 dan hb3. Zeit, et al. (2003) dalam Eads, et al. (2007) menyatakan konsentrasi mRNA sub unit hb2 dan hb3 meningkat selama kondisi hypoxia, namun tidak demikian halnya dengan sub unit hb1. Gorr, et al. (2006) dalam Eads, et al. (2007) mengidentifikasi adanya ikatan Juvenoid Respon Element (JRE) dengan Juvenoid Hormon Analoge (JHA) di wilayah promotor region gen hb2. penambahan pyriproxyten (JHA) mengaktifasi sintesa mRNA hb2 haemoglobin Daphnia magna. Hasil penelitian lain Gorr, et al. (2004) dalam Eads, et al. (2007) menyatakan bahwa ikatan Hypoxia Inducible Factor (HIF) dengan Hypoxia Response Element (HRE) juga ditemukan di promotor region dari gen hb2 Daphnia magna. Hal ini menunjukkan, sintesa haemoglobin Daphnia magna dipengaruhi oleh jalur signal terpenoid dari hormon Methyl Farnosoate dan jalur hypoxia.

Hasil penelitian ini menunjukkan bahwa pemaparan konsentrasi kadmium yang mempengaruhi jumlah jenis kelamin jantan tidak berpengaruh terhadap perubahan warna pada Daphnia magna. Hal ini disebabkan karena dalam kondisi oksigen terlarut (DO) tinggi yang berkisar antara 8,5 - 9,0, Methyl Farnesoate tidak mampu menginduksi produksi haemoglobin serta pada prinsipnya pembentukan haemoglobin di dalam tubuh Daphnia magna merupakan bentuk adaptasi terhadap toleransi oksigen terlarut yang rendah. Seperti halnya, Ebert (2005) yang menyatakan bahwa pada kondisi tersebut, Daphnia magna akan membentuk haemoglobin dalam hemolymph untuk membantu pendistribusian oksigen dalam tubuhnya. Adanya haemoglobin dalam hemolymph tersebut menyebabkan Daphnia magna berwarna merah. Namun, ketika oksigen tinggi, sintesa haemoglobin bukan merupakan suatu kebutuhan.

Berdasarkan pengukuran parameter kulitas air pada awal dan akhir penelitian, kualitas air secara umum berada pada kondisi optimal untuk kelangsungan hidup Daphnia magna. Oksigen terlarut pada penelitian ini berada pada kisaran 8,5 - 9,0 mg/l. Kisaran tersebut berada pada kisaran optimum untuk kelangsungan hidup Daphnia magna. Daphnia magna dapat bertahan hidup dalam konsentrasi oksigen terlarut minimal sebesar $3 \mathrm{mg} / \mathrm{l}$ (Ebert, 2005).

Suhu air selama penelitian terukur sebesar $26^{\circ} \mathrm{C}$. Suhu tersebut masih berada pada kisaran optimum pertumbuhan Daphnia magna yang berkisar antara $22-31{ }^{\circ} \mathrm{C}$ (Clare, 2002). Derajat keasaman $(\mathrm{pH})$ dalam penelitian ini berada pada kisaran optimum bagi kelangsungan hidup Daphnia magna, yaitu sebesar 8,0 - 8,2. Clare (2002) menyatakan bahwa derajat keasaman $(\mathrm{pH})$ optimum Daphnia magna berkisar antara 7,2 - 8,5. Kondisi kualitas air pada penelitian ini secara umum berada pada kisaran optimum sehingga faktor lain selain pengaruh perlakuan kadmium $\left(\mathrm{CdCl}_{2}\right)$ yang mempengaruhi perubahan warna dan pembentukan anakan kelamin jantan Daphnia magna dapat dikontrol.

\section{Kesimpulan}

Perlakuan konsentrasi kadmium $\left(\mathrm{CdCl}_{2}\right)$ yang berbeda terhadap 20 ekor Daphnia magna betina matang ovari selama 48 jam tidak memberikan pengaruh yang berbeda pada tingkat perubahan warna Daphnia magna karena kondisi oksigen terlarut (DO) yang tinggi Methyl Farnesoate tidak mampu menginduksi produksi haemoglobin.

Peningkatan konsentrasi kadmium $\left(\mathrm{CdCl}_{2}\right)$ yang dipaparkan pada induk Daphnia magna berkolerasi positif terhadap jumlah anakan jantan yang dihasilkan, semakin tinggi konsentrasi kadmium $\left(\mathrm{CdCl}_{2}\right)$ yang dipaparkan, semakin besar pula jumlah anakan jantan yang dihasilkan. Pemaparan konsentrasi kadmium $\left(\mathrm{CdCl}_{2}\right)$ pada konsentrasi $0,0004 \mathrm{mg} / \mathrm{l}$ (LC 50) menghasilkan anakan jantan $100 \%$.

Diharapkan adanya penelitian pada Daphnia magna terhadap berbagai tingkat oksigen terlarut terhadap perubahan warna Daphnia magna untuk lebih memberikan informasi yang tepat dalam mendukung penelitian ini maupun pengembangan penelitian tentang pencemaran perairan selanjutnya. Sebaiknya perlu dilakukan uji kandungan logam berat terhadap media air yang digunakan untuk uji toksisitas agar hasil yang didapatkan lebih akurat.

\section{Daftar Pustaka}

Clare, J. 2002. Daphnia an Aquarist's Guide. Dalam: http: // www. Caudata. Org/ daphnia. 13 hal.

Connell, D. W. and Milller, G. J. 1995. Kimia dan Ekotoksikologi Pencemaran. Terjemahan: Yanti Koestoer. Penerbit Universitas Indonesia Press. Jakarta. hal. 52-337. 
Eads, B., J. Andrews, and J. K. Coolbourne. 2007. Ecological Genomic in Daphnia: Stress Responses and Environmental Sex Determination. Center For Genomic and Bioinformatics. Indiana University Bloomington. Departement of Biology. USA.

Ebert, D. 2005. Ecology, Epidemiology, and Evolution of Parasitism in Daphnia. University of Basel. Switzerland. 11 hal.

Darmono. 1995. Logam Dalam Sistem Biologi Makhluk Hidup. Universitas Indonesia Press. Jakarta. hal 6-85.

Deken, A. 2005. Seeing Red: Daphnia and Hemoglobin. Ste. Genevieve du Bois School. Warson Woods, Missouri. Summer Reseach Fellowship for Science Teachers. Washington University Science Outreach. Missouri. Hal 2-8.

Hodkinson, I. D. 2005. Terrestrial and Aquatic Invertebrates as Bioindicators of Environmental Monitoring, With Particular References to Mountain Ecosystems. Liverpool John Moores University, Byrom Street. Liverpool. pp 649-666.

Joniansyah. 2004. Reklamasi Pantai Mutiara Dadap Merusak Lingkungan. Tempo Interaktif, 7 Juli 2004: 2

Kusriningrum, R. S. 2008. Perancangan Percobaan. Airlangga University Press. Surabaya. Hal 43-50.

Laufer, H. and Biggers, W. J. 2001. Unfying Concepts from Methyl Farnesoate for Invertebrate Reproduction and Post Embryonic Development. Departement of Molecular and Cell Biology. University of Connecticut. Massachussetts. pp. 442- 457.

LeBlanc, G. A., W. A. Olmsteated, X. Mu, Y. W. Helen, R. Bethany and Hong Li. 2006. Mechanictic Approaches to Screening Chemicals for Endocrine Toxicity Using an Invertebrate. Depatement of Environtmental and Moleculer Toxicology. North Carolina State University, Raleigh NC. http: // www. Epa.gov. 14/06/08. 1 hal.

Louekari, K., Kurtto, R. M. Pasanen, J. Virtanen. 2000. Cadmium In Fertilizers- Risk to Human Health and the Environtment. Ministry of Agriculture and Forestry. Finlandia. pp. 4-70.

Mudjiman, A. 1995. Makanan Ikan. Penebar Swadaya. Jakarta. Hal 28-37.
Mokoginta, I. 2003. Modul Budidaya Daphnia. Direktorat Pendidikan Menengah Kejuruan. Direktorat Jenderal Pendidikan Dasar dan Menengah. Departemen Pendidikan Nasional. Hal 25-26.

Ochlan. J. and V. S. Ochlman. 2003. Endocrine Disruption in Invertebrata. Pure Applechem. Vol 75. pp 11-12

Olmsteated and LeBlanc. 2002a. Effect of Endocrine Active Chemical on The Development of Sex Characteristic of Daphnia Magna. Departement of Toxicology North Caroline. USA. pp 731-735.

Olmsteated and LeBlanc. 2002b. The Juvenoid Hormon Methyl Farnesoate is a Sex Determinant in the Crustacean Daphnia Magna. Departement of Toxicology North Caroline. USA. pp $736-739$.

Olmsteated, W. A. 2003. Environtmental Toxicant Effect on Sexual Reproduction in Daphnia Magna. Dissertasions submitted to the Graduate Faculty of North Caroline State University. USA. 7 hal.

Rider, C. V., T. A. Gorr., A.W. Olmstead, B. A. Wasilak, and G. A. LeBlanc. 2005. Stress Signaling: Coregulation of Hemoglobin and Male Sex Determination Through a Terpenoid Signaling Pathway in a Crustacean. Departement of Environmental and Molecular Toxicology. North Carolina State University, Raleigh. USA. p. 1523.

Rottman, R. W., J. S. Graves, C. Watson and R. P. E. Yanong. 2003. Culture Techniques of Moina: The Ideal Daphnia For Feeding Freshwater Fish Fry. Departement of Fisheries and Aquatic Sciences, University of Florida. http:// www. Simply Discus.com. 12/05/08. 8 hal.

Rusdyanto, E., R. A. Wulandari, A. M. Wardiati, A. Winata, Hewindati dan B. Hardjojo. 1996. Kimia Fisik Biologi Lingkungan. Universitas Terbuka. Jakarta. hal. 15-57.

Samsubar, S. 1996. Statistik Nonparametrik Edisi 2. BPFE-Yogyakarta. Yogyakarta. hal. 27-38.

Setyawan. 2001. Pengertian Air Dari Perspektif Hukum Pusat Pengendalian Pencemaran Air. BPLHD Jawa Barat. 2 hal. 
Setyorini, D. 2003. Waspadai Bahaya Merkuri di Sumber Air Kita. Ecological Observation and Wetlands Conversation. Ecoton. Gresik. 2 hal.

Sunarto. 2007. Bioindikator Pencemar Logam Berat (Cd) Dengan Analisis Struktur Mikroanatomi, Efisiensi Fungsi Insang, Morfologi dan Kondisi Cangkang Kerang Air Tawar (Anondonta woodiana Lea). Tesis. Program Pasca Sarjana. Universitas Airlangga. Surabaya. 14 hal.
Soemirat, S, J. 1994. Kesehatan Lingkungan. Gadjah Mada University Press. Yogyakarta. hal. 10-75.

USEPA. 1996. Aquatic Invertebrate Acute Toxicity Test Freshwater Daphnids. Report. No. EPA-712C-96-114. United States Environmental Protection Agency, Washington, D. C. p. 96-114.

Zairin, Jr. M. 2002. Sex Reversal, Memproduksi Benih Ikan Jantan atau Betina. Penebar Swadaya. Jakarta. hal. 1- 88. 